\title{
Fractional Calcium Current through Neuronal AMPA-Receptor Channels with a Low Calcium Permeability
}

\author{
Filippo Tempia, Masanobu Kano, Ralf Schneggenburger, Claudia Schirra, Olga Garaschuk, Timothy Plant, \\ and Arthur Konnerth
}

1. Physiologisches Institut der Universität des Saarlandes, 66421 Homburg, Germany

The $\mathrm{Ca}^{2}$ ' -permeation properties of AMPA-receptor (AMPA-R) channels in Purkinje neurons in rat cerebellar slices were studied using a combination of whole-cell patch-clamp recordings, Fura-2 fluorometry, and single-cell reverse-transcription (RT)PCR. Several lines of evidence indicate that Purkinje neurons, at both early and late stages of postnatal development, express exclusively AMPA-R channels with a low $\mathrm{Ca}^{2+}$ permeability. First, no $\mathrm{Ca}^{2+}$ signal was detected during application of either AMPA or kainate to Purkinje neurons loaded with the $\mathrm{Ca}^{2+}$ indicator Fura-2 AM. In contrast, kainate application induced large $\mathrm{Ca}^{2+}$ transients in Bergmann glia cells. Second, in ion substitution experiments, when $\mathrm{Ca}^{2+}$ is the only extracellular permeant cation, the reversal potential corresponds to that expected for AMPA-R channels with a low permeability for $\mathrm{Ca}^{2+}$. Third, using a fluorometric flux-measurement approach (Schneggenburger et al., 1993a), we found that the $\mathrm{Ca}^{2+}$ fraction of the total cation current through AMPA-R channels is $\sim 0.6 \%$. This value is approximately sixfold lower than that found for recombinant AMPA-R lacking the AMPA-R subunit GluR2. Furthermore, single-cell RT-PCR experiments revealed the presence of the AMPA-R subunits GluR1, GluR2, and GluR3 in Purkinje neurons in cerebellar slices at developmental stages corresponding to those studied electrophysiologically. The expression of GluR2 in all cells tested $(n=14)$ is consistent with the subunit composition predicted from studies of recombinant AMPA-R channels with a low permeability for $\mathrm{Ca}^{2+}$ (Burnashev et al., 1992b). In conclusion, this study establishes that cerebellar Purkinje neurons at all postnatal developmental stages possess AMPA-R channels with a low permeability for $\mathrm{Ca}^{2+}$.

Key words: AMPA-receptor channels; $\mathrm{Ca}^{2+}$ permeability; fractional $\mathrm{Ca}^{2+}$ current; Purkinje neurons; postnatal development; patch clamp; cerebellar slices; single-cell RT-PCR; Fura-2; ester loading; digital fluorometric imaging
Purkinje neurons of the cerebellar cortex are an interesting cellular model to study the $\mathrm{Ca}^{2+}$ permeability properties of neuronal AMPA receptors (AMPA-R), the receptors that mediate fast glutamatergic synaptic transmission. This is because there is relatively detailed information on the expression of mRNA for the four AMPA-R subunits (GluR1-GluR4) in Purkinje neurons, both from in situ hybridization studies (Keinänen et al., 1990; Sommer et al., 1990; Monyer et al., 1991) and from the single-cell reverse-transcription (RT)-PCR approach (Lambolez et al., 1992). Results using both approaches indicate that a wide range of AMPA-R subunits, including the edited form of GluR2 [commonly known as GluR2(R)], the expression of which determines the $\mathrm{Ca}^{2+}$ permeability properties of AMPA-R (Hollmann et al., 1991; Hume et al., 1991; Burnashev et al., 1992b) (for revicw, sce Seeburg, 1993; Hollmann and Heinemann, 1994), is expressed in cerebellar Purkinje neurons. There is some disagreement, however, concerning the expression of GluR2 subunits in Purkinje neurons at early postnatal developmental stages (Pellegrini-

\footnotetext{
Received July 25, 1995; revised Oct. 16, 1995; accepted Oct. 18, 1995.

This work was supported by grants from the Deutsche Forschungsgemeinschaft (SFB 246) and the Bundesministerium für Bildung, Wissenschaft, Forschung und Technologic. M.K. was supported by fellowships from the Alexander von Humboldt Foundation and the International Human Frontier Science Program. We thank Nicole Wilhelm for excellent technical help.

Correspondence should be addressed to Dr. Timothy D. Plant at the above address.

Current addresses arc as follows. Dr. Tempia: Department of Human Anatomy and Physiology, Corso Raffaello 30, 10125 Torino, Italy. Dr. Kano: Laboratory for Neuronal Signal Transduction, Fronticr Research Program, RIKEN, Wako 351-01, Japan. Dr. Schneggenburger: Laboraluire de Neurubiologie, Ecole Nornale Supérieure, Rue d'Ulm 46, 75005 Paris, France.

Copyright 1996 Society for Neuroscience 0270-6474/96/160456-11\$05.00/0
}

Giampietro et al., 1992). In addition, Purkinje neurons are devoid of functional NMDA receptors (Perkel et al., 1990; Farrant and Cull-Candy, 1991; Llano et al., 1991b) (but see Momiyama et al., 1995). Furthermore, $\mathrm{Ca}^{2+}$ signaling in Purkinje neurons is associated with several important functions such as the long-term modification of two different synaptic inputs, one glutamatergic

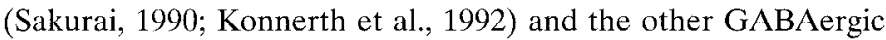
(Llano et al., 1991a; Kano et al., 1992). Therefore, it is necessary to determine to what degree AMPA-R channels can contribute directly to $\mathrm{Ca}^{2+}$ signaling in Purkinje neurons. Recent studies, using the technique of Fura- 2 ester loading in isolated Purkinje neurons, found a relevant $\mathrm{Ca}^{2+}$ accumulation after activation of AMPA-R (Brorson et al., 1992; Sorimachi, 1993). However, another report in cultured Purkinje neurons suggested the presence of AMPA-R channels with a low permeability for $\mathrm{Ca}^{2+}$ (Linden et al., 1993).

In the present study, we have combined different methodological approaches to study the $\mathrm{Ca}^{2+}$-permeability properties of AMPA-R in Purkinje neurons in rat cerebellar slices. Using the Fura-2 ester-loading technique, the intracellular $\mathrm{Ca}^{2+}$ concentration $\left(\left[\mathrm{Ca}^{2+}\right]_{\mathrm{i}}\right.$ ) changes evoked by AMPA-R agonists in Purkinje neurons from cerebellar slices of young [postnatal days 1-15 (P1-P15)] rats were compared with those in Bergmann glial cells, which are known to express AMPA-R with a high $\mathrm{Ca}^{2+}$ permeability (Burnashev et al., 1992a; Müller et al., 1992). The electrophysiological properties of AMPA- and kainate-induced currents were determined using whole-cell patch-clamp recordings and ion-substitution experiments. To resolve and quantify the fractional contribution of $\mathrm{Ca}^{2+}$ to the total current through AMPA-R 
in Purkinje neurons, we used a technique based on loading the cell via the patch pipette with high concentrations of Fura-2 (Neher and Augustine, 1992; Schneggenburger et al., 1993a). The singlecell RT-PCR technique was used to identify the AMPA-R mRNA expressed in Purkinje neurons from young rats and, in particular, to look for the presence of GluR2. Finally, using the combination of patch-clamp recording and ratiometric digital imaging of soma and dendrites of Purkinje neurons, we tested for the presence of relevant $\mathrm{Ca}^{2+}$ signals associated with currents evoked by AMPA-R agonists.

\section{MATERIALS AND METHODS}

Slice preparation and whole-cell patch-clamp recordings. Sagittal cerebellar slices (200 $\mu \mathrm{m}$ thickness) were obtained from 1- to 38-d-old rats following the methods originally described by Llinás and Sugimori (1980), with slight modifications (Edwards et al., 1989; Llano et al., 1991a; Kano and Konnerth, 1992). The slices were kept at $34^{\circ} \mathrm{C}$ in oxygenated standard saline (scc bclow) for at least for $1 \mathrm{hr}$ before transferring them to the experimental setup. The Purkinje neuron surface was cleaned, and tightseal whole-cell recordings were established as previously described (Edwards et al., 1989). All experiments were performed at room temperature in experimental setups with upright microscopes (either Standard or Axioskop; Zeiss, Jena, Germany), using a $40 \times$ water-immersion objective and epifluorescence optics (see below). Unless otherwise specified, the experimental chamber was perfused continuously with the standard saline containing (in mM): $125 \mathrm{NaCl}, 2.5 \mathrm{KCl}, 2 \mathrm{CaCl}_{2}, 1 \mathrm{MgCl}_{2}, 1.25 \mathrm{NaH}_{2} \mathrm{PO}_{1}$, $26 \mathrm{NaHCO}_{3}$, and 20 glucose. This solution was bubbled with $95 \% \mathrm{O}_{2} / 5 \%$ $\mathrm{CO}_{2}$ to maintain $\mathrm{pH} 7.4$. Patch pipettes had resistances between 2.0 and

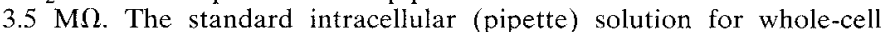
recordings contained (in $\mathrm{mM}$ ): $140 \mathrm{CsCl}, 2 \mathrm{MgCl}_{2}, 1 \mathrm{CaCl}_{2}, 10 \mathrm{Cs}$-EGTA $10 \mathrm{Cs}-\mathrm{HEPES}$, and $2 \mathrm{Na}_{2}-\mathrm{ATP}, \mathrm{pH} 7.3$. The composition of the intracellular solution was different in the $\left[\mathrm{Ca}^{2+}\right]_{\mathrm{i}}$-imaging experiments and for the measurements of fractional $\mathrm{Ca}^{2+}$ currents (see below). During wholecell recording, the holding potential was set to $-60 \mathrm{mV}$ unless indicated otherwise. In the ion-substitution experiments (Fig. 3), the perfusate had the following composition (in $\mathrm{mM}$ ): $130 \mathrm{~N}$-methyl-D-glucamine-Cl (NMG), $10 \mathrm{CaCl}_{2}, 10 \mathrm{HEPES}$, and 20 glucose, $\mathrm{pH}$ 7.4. Leak-subtracted voltage ramps (from a holding potential of +60 to $-60 \mathrm{mV}, 300 \mathrm{msec}$ duration) were used to construct current-voltage relationships of the agonist-activated currents. Agonists and other pharmacological agents were bath-applied by exchanging the perfusion medium, except in the case of measuring fractional $\mathrm{Ca}^{2+}$ currents, in which agonists were applied using an iontophoresis system (NPI Electronic, Tamm, Germany). All substances were purchased from Sigma (Deisenhofen, Germany), except for Fura-2, Fura-2 AM (Molecular Probes, Eugene, OR), and D600, which was a gift from Knoll (Ludwigshafen, Germany).

Imaging of $\left[\mathrm{Ca}^{2+}\right]_{i}$ changes. For imaging $\left[\mathrm{Ca}^{2+}\right]_{\mathrm{i}}$ changes (Figs. 2, 6), a digital-imaging system (VPROBE; ETM-Systems, Mission Viejo, CA) was used. In patch-clamp experiments, background images of the preparation were constructed from the $360 / 380$ fluorescence ratio while the pipette was in the cell-attached mode. After establishment of the wholecell configuration, paired exposures to 360 and $380 \mathrm{~nm}$ were used to construct background-corrected digital fluorescence ratio images (DFI) These images were displayed on-line on a monitor using a pseudocolor format and stored on disk for later analysis. Off-line analysis of DFI was performed to calculate $\left[\mathrm{Ca}^{2+}\right]_{i}$ from the fluorescence ratio $360 / 380$, according to Grynkiewicz et al. (1985). The intracellular (pipette) solution for patch-clamp measurements and simultaneous $\left[\mathrm{Ca}^{2+}\right]_{\mathrm{i}}$ imaging contained (in mM): $75 \mathrm{Cs}$-gluconate, $75 \mathrm{CsCl}, 4 \mathrm{MgCl}_{2}, 0.1 \mathrm{CaCl}_{2}, 0.5$ Cs-EGTA, $10 \mathrm{Cs}$-IIEPES, $0.3 \mathrm{Na}-\mathrm{GTP}, 2 \mathrm{Na}_{2}$-ATP, and 0.2 Fura-2, pII 7.2. For $\left[\mathrm{Ca}^{2+}\right]_{i}$ imaging of various cell types within the cerebellar slices (see Fig. 2), the cells were loaded with Fura-2 AM. The cerebellar slices were placed in oxygenated standard saline containing Fura-2 AM (10 $\mu \mathrm{M})$ immediately after cutting. One to three hours later, they were transferred to oxygenated saline and excess Fura-2 AM was washed away. The slices were placed in the recording chamber of the experimental setup, and the background fluorescence was taken from a region that was located near the cell of interest. These background regions were devoid of Fura-2 fluorescence arising from surrounding cells, as visually estimated from the fluorescence images displayed on-line. The cells were stimulated by bath application of high $\mathrm{K}^{+}$saline and/or AMPA-R agonists. To measure the response in terms of $\left[\mathrm{Ca}^{2+}\right]_{\mathrm{i}}$, the fluorescence intensities were computed by the digital-imaging system for several regions of interest and sent via a serial line to an analyzing computer (Macintosh IIfx), by which $\left[\mathrm{Ca}^{2+}\right]_{\mathrm{i}}$ was calculated from the background-corrected fluorescence ratio $360 / 380$ $\mathrm{nm}$ according to the relation given by Grynkiewicz et al. (1985).

Measurement of fractional $\mathrm{Ca}^{2+}$ currents. Estimates of the fractional $\mathrm{Ca}^{2+}$ current $\left(P_{f}\right)$ through AMPA-R were performed in Purkinje neurons of cerebellar slices from 4-to 7-d-old rats. At this developmental stage, the dendrites of Purkinje neurons are still small (Altmann, 1972). This allows good space- and voltage-clamp conditions for the recording of voltage-gated $\mathrm{Ca}^{2+}$ currents (see below), and also allows $\mathrm{Ca}^{2+}$ influx over the entire cellular area to be averaged spatially. Fura-2 fluorescence measurements were done with a photomultiplier that collected the fluorescence of a $50-\mu \mathrm{m}$-diameter circular area, into which the cell was placed. Fura-2 was excited alternately at 360 and $380 \mathrm{~nm}$ wavelengths using a filter wheel (Luigs \& Neumann, Ratingen, Germany) rotating at $4 \mathrm{~Hz}$. The fluorescence signals were sampled at $2 \mathrm{~Hz}$ and thus represent spatial and temporal averages. The absolute fluorescence intensities at $380 \mathrm{~nm}$ were normalized to the fluorescence, at the same wavelength, of standard fluorescent beads $(4.5 \mu \mathrm{m}$ diameter; Polysciences, Warrington, PA). The resulting fiuorescence unit was termed $1 \mathrm{BU}$ (for elaboration, see Schneggenburger et al., 1993a; Zhou and Neher, 1993). During the loading of Purkinje neurons with $1 \mathrm{~mm}$ Fura-2, voltage-gated $\mathrm{Ca}^{2+}$ currents were elicited by short $(50-250 \mathrm{msec})$ depolarizing voltage steps $\left(V_{\mathbf{H}}=-60 \mathrm{mV}\right.$, steps to $+10 \mathrm{mV}$ ). Current components through other voltage-gated channels were blocked by using an intracellular solution aimed at blocking voltage-gated $\mathrm{K}^{+}$currents [(in $\mathrm{mM}$ ): $130 \mathrm{CsCl}, 20$ tctracthylammonium (TEA), 10 HEPES, 4 Mg-ATP, $0.2 \mathrm{Na}$-GTP, 1 Na-cAMP, 1 Fura-2, $\mathrm{pH} 7.3$ ] and by supplementing the extracellular solution with $0.5 \mu \mathrm{M}$ tetrodotoxin (TTX) to block voltage-gated $\mathrm{Na}^{+}$ currents. The changes in fluorescence at $380 \mathrm{~nm}$ produced by voltagegated $\mathrm{Ca}^{2+}$ currents were divided by the charge measured as the time integral of the current, giving the $F / Q$ ratio. When, during diffusion of Fura-2 into the cell, the increase of the $F / Q$ ratio saturates approaching a value $F_{\text {max }}$, it can be assumed that almost all $\mathrm{Ca}^{2+}$ entering the cell is captured by Fura-2 (Neher and Augustine, 1992). Therefore, $F_{\max }$ is the conversion factor between fluorescence change and $\mathrm{Ca}^{2+}$ charge. The $F_{\text {nax }}$ value determined in the present study [8.4 BU/nanocoulomb (nC)] was obtained by applying depolarizing steps to activate voltage-gated $\mathrm{Ca}^{2+}$ channels during the loading of cells with Fura-2, and is similar to that obtained in other studies (Schneggenburger et al., 1993a; Zhou and Neher, 1993; Burnashev et al., 1995; Garaschuk et al., in press). The attainment of saturating $F / Q$ values was controlled by plotting the $F / Q$ ratio as a function of the $\mathrm{Ca}^{2+}$-buffer capacity of Fura-2, as described by Neher and Augustine (1992). It has been reported recently that $F_{\max }$ values obtained by $\mathrm{Ca}^{2+}$ permeation through ligand-gated channels differ from those obtained by application of depolarizing voltage steps (Rogers and Dani, 1995). Our results, therefore, could underestimate slightly the fractional $\mathrm{Ca}^{2+}$ current through AMPA-R channels. However, Rogers and Dani (1995) found that the difference between values obtained using the two calibration methods was small when the fractional $\mathrm{Ca}^{2+}$ current was small. Furthermore, they also found that the difference was smaller in more spherical cells than in cells with dendrites, probably because of differences in the spatial distribution of voltage- and ligand-gated channels in the latter. At the stage of development used for the measurements in this study, most Purkinje neurons have not developed a relevant dendritic tree (Altman, 1972), thus reducing this kind of error. Under conditions where the $F / Q$ ratio has reached saturation, the $F / Q$ ratio measured for a nonselective cation channel is smaller than $F_{\max }$ and can be converted directly into fractional $\mathrm{Ca}^{2+}$ current (Schneggenburger et al., 1993a). The measurements for ligand-gated channels were performed on a separate population of Purkinje neurons from those used to determine $F_{\text {max }}$. To improve the accuracy of the analysis of $F / Q$ ratios for $\triangle M P \Lambda$ and kainate evoked currents, which produce tiny changes in fluorescence, we estimated the $F / Q$ ratio by fitting the fluorescence signal with a simulation derived from the current trace (for details, see Schneggenburger et al., 1993a). All of the measurements of fractional $\mathrm{Ca}^{2+}$ current were done by taking the $F / Q$ ratio that best-fitted the fluorescence data points using this simulation. By dividing the experimentally determined $F / Q$ ratio by $F_{\text {max }}$, an estimate of the fractional $\mathrm{Ca}^{2+}$ current can be obtained (Schneggenburger et al., 1993a; Zhou and Neher, 1993).

RT-PCR on single Purkinje neurons. For the single-cell RT-PCR analysis, the contents of single Purkinje neurons were harvested via the patch pipette (resistance $1.8-2 \mathrm{M} \Omega$ ) by applying negative pressure for $5-10 \mathrm{~min}$ after establishment of the whole-cell configuration. The patch pipette was filled with $8 \mu$ l of an autoclaved solution containing (in $\mathrm{mM}$ ): $140 \mathrm{CsCl}, 3$ 
$\mathrm{MgCl}_{2}, 5$ EGTA, 10 HEPES, pH-adjusted to 7.2 with CsOH. To avoid contamination of mRNAs from other sources, a high-resistance electrical contact between cell membrane and patch pipette was maintained throughout harvesting. The RT reaction was performed using Moloney murine leukemia virus reverse transcriptase (Gibco, Eggenstein, Germany) for $1 \mathrm{hr}$ at $37^{\circ} \mathrm{C}$, as described in detail by Lambolez et al. (1992). The $10 \mu \mathrm{l}$ of mix then was stored at $-80^{\circ} \mathrm{C}$ until use for amplification by PCR.

During the first PCR reaction, a common primer pair was used to amplify a fragment of GluR1-GluR4 cDNAs (primers as in Lambolez et al., 1992). The final reaction volume of $100 \mu \mathrm{l}$ contained the $10 \mu \mathrm{l}$ of RT-reaction mixture (in which each deoxyribonucleotide had a concentration of $0.5 \mathrm{~mm}$ ), $10 \mathrm{pmol}$ of each primer, $10 \mu \mathrm{l}$ of $10 \times$ Taq polymerase buffer (Stratagene, Heidelberg, Germany), and $2.5 \mathrm{U}$ of Taq polymerase (Stratagene). PCR was performed with a programmable thermocycler (Biometra, Göttingen, Germany) under the following conditions: 5 cycles $\left(94^{\circ} \mathrm{C}, 30 \mathrm{sec} ; 45^{\circ} \mathrm{C}, 30 \mathrm{sec}\right.$; ramp to $\left.72^{\circ} \mathrm{C}, 1 \mathrm{~min}, 10 \mathrm{sec} ; 72^{\circ} \mathrm{C}, 1 \mathrm{~min}\right)$ followed by 35 cycles $\left(91^{\circ} \mathrm{C}, 30 \mathrm{sec} ; 19^{\circ} \mathrm{C}, 30 \mathrm{sec} ; 72^{\circ} \mathrm{C}, 1 \mathrm{~min}\right)$. The reaction mixture $(10 \mu \mathrm{l})$ then was analyzed by agarose-gel electrophoresis (1.5\% low-melting agarose gel containing ethidium bromide). The size and the amount of amplified DNA band were compared with the bands of the molecular-weight marker ( $\Phi X 174 / \mathrm{HaeIII})$. The agarose band containing the PCR fragment was cut under ultraviolet illumination. To obtain a sufficient amount of amplified GluR1-GluR4 tragments for restriction analysis, the melted agarose band was used as a template for the second PCR reaction with the same set of primers. The final reaction volume of $100 \mu \mathrm{l}$ contained $0.5-5 \mu \mathrm{l}$ of the melted agarose (depending on the amount of DNA in the band), $10 \mathrm{pmol}$ of each primer, $50 \mu \mathrm{M}$ each deoxyribonucleotide, $10 \mu \mathrm{l}$ of $10 \times \mathrm{Taq}$ buffer (Stratagene), and $2.5 \mathrm{I}$ of Taq polymerase (Stratagene). After 35 cycles $\left(94^{\circ} \mathrm{C}, 30 \mathrm{sec} ; 49^{\circ} \mathrm{C}, 30 \mathrm{sec}\right.$; $72^{\circ} \mathrm{C}, 1 \mathrm{~min}$ ), a chloroform-isoamylalcohol extraction and an ethanol precipitation were performed. Aliquots $(2 \mu \mathrm{l})$ of the DN $\Lambda$, resuspended in $20 \mu \mathrm{l} \mathrm{H}_{2} \mathrm{O}$, were digested by a subunit-specific restriction enzyme. The four enzymes, BglI (Stratagene), Bsp1286I (Promega, Serva, Heidelberg,
Germany), Fco47III, and EcoRI (both from Stratagene), selectively cut the GluR1, -2, -3, and -4 PCR fragments, respectively. The restriction reaction then was analyzed by agarose-gel electrophoresis as described above. Controls were performed in parallel using water or RNA from the whole brain. The total RNA was prepared using a guanidinium thiocyanate single-step method (Chomczynski and Sacchi, 1987).

To perform Southern blot analysis controls after agarose-gel electrophoresis, the DNA fragments present in a gel were transferred onto a nylon membrane (positively charged, Boehringer Mannheim, Mannheim, Germany). The resulting Southern blot then was hybridized with one of the GluR1to GluR4-specific probes. The probes were prepared from Bluescript plasmids containing the entire coding sequence of GluR1flop. GluR2flop, GluR3flop, or GluR4flip (gifts from J. Boulter, The Salk Institute, La Jolla, CA) by randomly primed labeling using the DIG DNA-labeling kit (Boehringer). The hybridization was performed with the DIG-labeled DNA probe dissolved in hybridization buffer [5× SSC, $0.1 \%$ (w/v) $N$-laurylsarcosine, $0.02 \%(\mathrm{w} / \mathrm{v}) \mathrm{SDS}$, and $1 \%$ dry milk] for at least $10 \mathrm{hr}$ at $68^{\circ} \mathrm{C}$. The hybridized probes were immunodetected with anti-digoxigenin Fab fragments conjugated to alkaline phosphatase and were visualized with the chemiluminescent substrate Lumigen PPD as described in the Detection kit for DIGlabeled nucleic acids (Boehringer).

\section{RESULTS}

\section{Separation of voltage- and ligand-gated $\mathrm{Ca}^{2+}$ fluxes}

A necessary prerequisite for the quantification of $\mathrm{Ca}^{2+}$ influx through ligand-gated ion channels with fluorometric methods is to block $\mathrm{Ca}^{2+}$ influx through voltage-gated $\mathrm{Ca}^{2+}$ channels, which may contaminate the measurements. For this purpose, the organic $\mathrm{Ca}^{2+}$-channel blocker D600 was used, which completely blocked voltage-gated $\mathrm{Ca}^{2+}$ currents of Purkinje neurons in cerebellar slices (Fig. $1 A-C$ ). Although a relatively high concentration (500
Figure 1. D600 blocks voltage-gated $\mathrm{Ca}^{2+}$ currents but not kainate-evoked currents. $A$, Patch-clamp recording of $\mathrm{Ca}^{2+}$ currents in a Purkinje neuron in a slice from a 5-d-old rat. The stimulation protocol consisted of depolarizing stcps with a duration of $50 \mathrm{msec}$ from a holding potential of $-80 \mathrm{mV}$ to the indicated potentials. $B$, Patch-clamp recording from the same neuron and with the same stimulation protocol as in $A$, but after $10 \mathrm{~min}$ of perfusion of the slice with a solution containing the $\mathrm{Ca}^{2+}$ channel blocker D600 $(500 \mu \mathrm{M})$. Same calibrations as in $A$. $C$, Current-voltage relationship of $\mathrm{Ca}^{2+}$ currents of the same Purkinje neuron as in $A$ and $B$. (-) Before D600; $(O)$ after $>10$ min of perfusion with a D600-containing extracellular solution. Holding potential was $-80 \mathrm{mV} . \mathrm{K}^{+}$currents were blocked by intracellular $\mathrm{Cs}^{+}(130 \mathrm{~mm})$ and $\mathrm{TEA}^{+}$ (20 mM). $\mathrm{Na}^{+}$currents were blocked by $\operatorname{TTX}(0.5 \mu \mathrm{M}) . D$, Current evoked in a Purkinje neuron from a 7-d-old rat by a bath application of kainate $(10 \mu \mathrm{M}) . E$, Current evoked in a Purkinje neuron by a bath application of kainate $(10 \mu \mathrm{M})$ after complete block of $\mathrm{Ca}^{2+}$ currents by D600 $(500 \mu \mathrm{M}$; same cell as in $D)$.
A

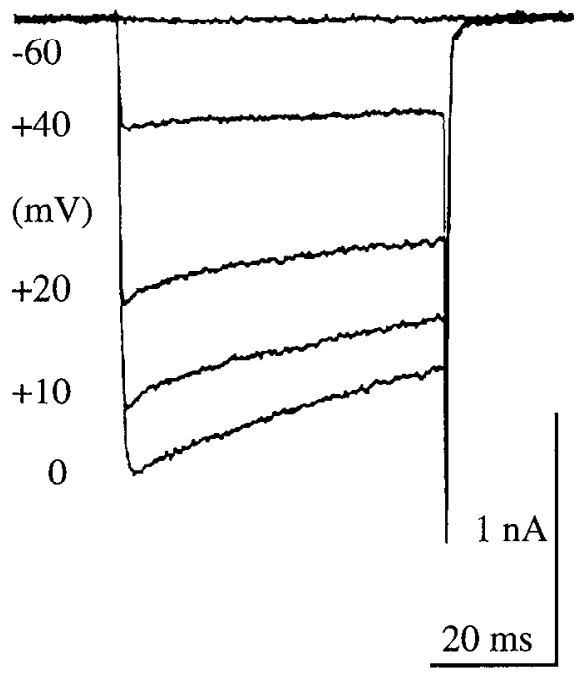

D control

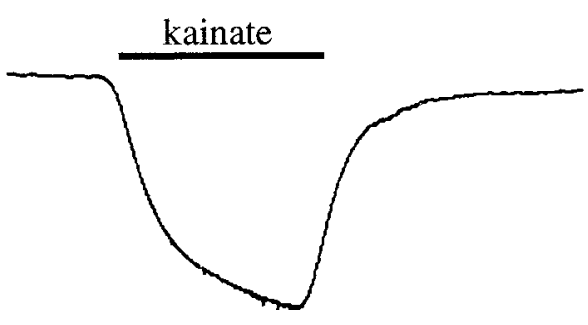

B D600

C

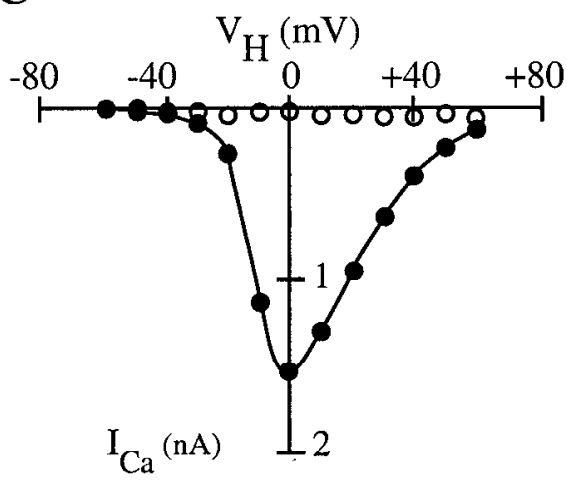

E D600

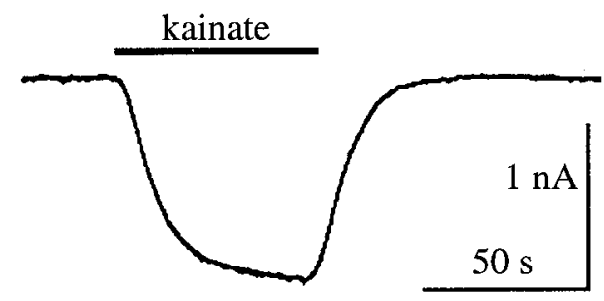




\section{A Bergmann glia}

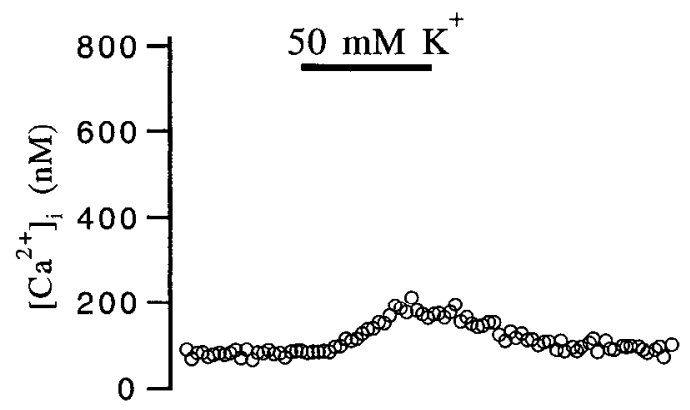

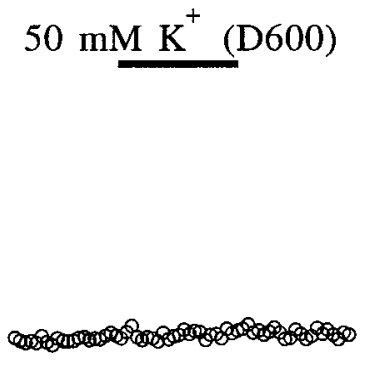

ore

$50 \mathrm{mM} \mathrm{K}^{+}(\mathrm{D} 600)$
$1 \mathrm{mM}$ kainate (D600)

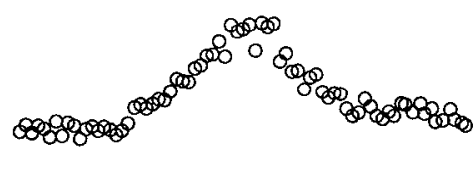

\section{B Purkinje neuron}

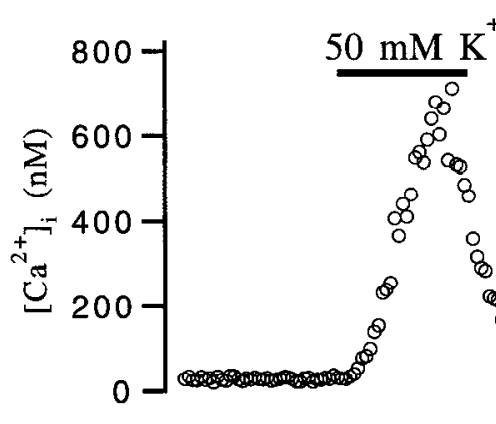

\section{Purkinje neuron}

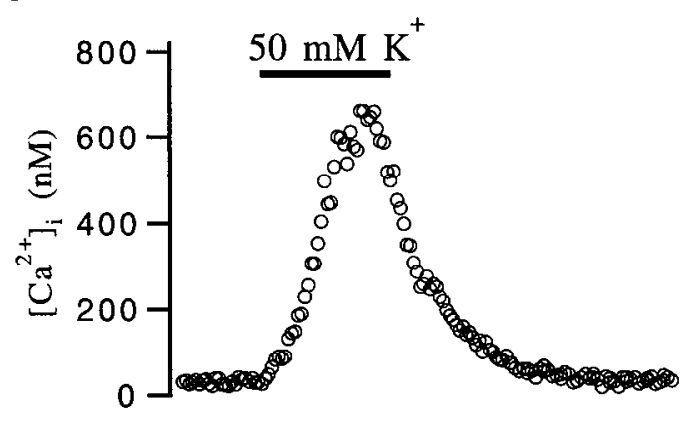

$50 \underline{\mathrm{mM} \mathrm{K}^{+}}(\mathrm{D} 600)$

$20 \underline{\mu M}$ AMPA (D600)

Figure 2. Fluorometric recording of $\left[\mathrm{Ca}^{2+}\right]_{\mathrm{i}}$ in rat cerebellar slices loaded with Fura-2 AM. Left, Changes in $\left[\mathrm{Ca}^{2+}\right]_{\mathrm{i}}$ induced by depolarizing the cells with a high concentration of extracellular $\mathrm{K}^{+}(50 \mathrm{~mm})$. Middle, Effects of the same high- $\mathrm{K}^{+}$applications after 10 min of perfusion with a solution containing D600 $(500 \mu \mathrm{M})$. Right, $\mathrm{Ca}^{21}$ responses to bath application of kainate $(A, B)$ or AMPA $(C)$. $A$, Response of a Bergmann glial cell in a cerebellar slice from a 20-d-old rat to kainate application $(1 \mathrm{~mm}) . B$, Response of a Purkinje neuron in a slice from a 1-d-old rat to bath application of kainate (1 mM). $C$, Response of a Purkinje neuron in a slice from a 2-d-old rat to bath application of AMPA $(20 \mu \mathrm{M})$.

$\mu \mathrm{M})$ was necessary to achieve a complete block of voltage-gated $\mathrm{Ca}^{2+}$ channels, the drug did not affect ionic currents evoked in Purkinje ncurons by bath-applied kainate (Fig. $1 D, E$ ). Similarly, currents induced by iontophoretic application of AMPA or kainate were not affected by the presence of $500 \mu \mathrm{M}$ D600 in the bath solution (data not shown). In the following experiments, therefore, D600 was used whenever a contaminating $\mathrm{Ca}^{2+}$ influx through voltage-gated channels had to be eliminated.

\section{Calcium responses to AMPA-R activation in Purkinje neurons and Bergmann glial cells loaded with Fura-2 AM}

To test whether $\mathrm{Ca}^{21}$ permeates through AMPA-R channels in Purkinje neurons in cerebellar slices, we monitored the changes in
$\left[\mathrm{Ca}^{2+}\right]_{\mathrm{i}}$ in Fura-2 AM-loaded cells. This is the same technique used in isolated Purkinje neurons in previous reports in which AMPA-R channcls werc found to have a significant $\mathrm{Ca}^{2+}$ permeability (Brorson et al., 1992; Sorimachi, 1993). This approach allowed us to monitor the responses of several cells simultaneously. Furthermore, it allowed us to compare the responses of Purkinje neurons with those of Bergmann glial cells, which are known to express $\mathrm{Ca}^{2+}$-permeable AMPA-R channels (Burnashev et al., 1992a; Müller et al., 1992). Bergmann glial cells were identified by their size, location, and morphology. A typical experimental protocol is illustrated in Figure 2. Initially, as a control for voltage-gated $\mathrm{Ca}^{2+}$ influx, the cells were depolarized by bath application of a solution containing $50 \mathrm{mM} \mathrm{K}^{+}$(Fig. 2, left). Then 
$500 \mu \mathrm{M}$ D600 was added to the bath solution, and the cells were depolarized repetitively by bath applications of $50 \mathrm{~mm} \mathrm{~K}^{+}$. Agonists of AMPA-R were applied only when the depolarizationinduced $\mathrm{Ca}^{2+}$ signals were blocked completely by D600 (Fig. 2, middle). In this experimental situation, bath applications of kainate led to clear increases in $\left[\mathrm{Ca}^{2+}\right]_{i}$ in Bergmann glial cells (Fig. $2 A$, right). The mean ( $\pm \mathrm{SD}$ ) increase in five cells with $1 \mathrm{~mm}$ kainate was $116 \pm 22 \mathrm{~nm}$. In contrast, the application of $1 \mathrm{~mm}$ kainate did not cause any detectable increase in $\left[\mathrm{Ca}^{2+}\right]_{\mathrm{i}}$ in 23 of 24 Purkinje neurons that underwent the complete experimental protocol. At the earliest age tested, P1-P2, 1 of 9 Purkinje neurons showed a response to the application of $1 \mathrm{~mm}$ kainate. At the later developmental stages studied, P3-P5 ( $n=10$ cells) and P9-P15 ( $n$ $=5$ cells), no response to kainate application was observed. Using the same protocol, the application of $20 \mu \mathrm{M}$ AMPA to 3 Purkinje neurons in a slice from a 2 -d-old rat did not evoke any detectable $\mathrm{Ca}^{2+}$ signal.

\section{Current-voltage relationship of the currents flowing through AMPA-R of Purkinje neurons in standard and in $\mathrm{Na}^{+}$-free, high-Ca ${ }^{2+}$ extracellular solutions}

In a second set of experiments, we directly measured the ionic currents through AMPA-R of Purkinje neurons from cerebellar slices by whole-cell patch-clamp recordings. Bath applications of AMPA $(1-10 \mu \mathrm{M} ; n=9$ cells) or kainate $(10-100 \mu \mathrm{M} ; n=10)$ induced inward currents at a holding potential of $-60 \mathrm{mV}$ in all Purkinje neurons studied. Figure $3 A$ (left) shows AMPA-induced currents of a Purkinje neuron of a 25-d-old rat. Outward and inward currents with peak amplitudes of $>1 \mathrm{nA}$ were induced at positive $(+60 \mathrm{mV})$ and negative $(-60 \mathrm{mV})$ holding potentials, respectively. The current-voltage relationship during application of AMPA to the same Purkinje neuron (Fig. 3A, right) was linear in the potential range from -60 to $+60 \mathrm{mV}$. Similar currents were induced in a Purkinje neuron of an 8-d-old rat by kainate (Fig. 3B, left). The current-voltage relationship of this cell was linear (Fig. $3 B$, right).

As a third experimental approach to the study of the $\mathrm{Ca}^{2+}$ permeability of AMPA-R, a solution was applied in which all extracellular monovalent cations were replaced by the impermeant cation NMG (Iino et al., 1990) and the $\mathrm{Ca}^{2+}$ concentration was raised to 10 $\mathrm{mm}$. Under these conditions, the only extracellular cation that can permeate through AMPA-R channels is $\mathrm{Ca}^{2+}$. Figure $3 C$ shows the responses of a Purkinje neuron of an 8-d-old rat to kainate in this 10 mM NMG Ca ${ }^{2+}$ solution. 'The current was outward even at a holding potential of $-60 \mathrm{mV}$ (Fig. 3C, left), and no inward current was obscrved over a potential range from 60 to $140 \mathrm{mV}$ (Fig. 3C, right). The same results were obtained in 8 Purkinje neurons from 6- to 9 -d-old rats. The reversal potentials in $10 \mathrm{mM} \mathrm{NMG} \mathrm{Ca}^{2+}$ solution always were more negative than $-60 \mathrm{mV}$.

\section{Fractional $\mathrm{Ca}^{2+}$ current through AMPA-R channels of Purkinje neurons}

Small amounts of $\mathrm{Ca}^{2+}$ influx, which may be too small to be detected using the techniques described above, can be resolved by measuring the changes in $\mathrm{Ca}^{2+}$-sensitive fluorescence in cells loaded with a high concentration of $\mathrm{Ca}^{2+}$-sensitive dye. In addition, if the membrane current is measured simultaneously, the contribution of $\mathrm{Ca}^{2+}$ to the total current can be determined. Therefore, Purkinje neurons were loaded with high concentrations (1-2 $\mathrm{mm}$ ) of Fura-2 via the patch pipette, and membrane currents and fluorescence were monitored during the iontophoretic application of AMPA-R agonists.

Purkinje neurons have particularly strong endogenous $\mathrm{Ca}^{2+}$. buffering mechanisms (Llano et al., 1994). It was established, therefore, whether a concentration of $1 \mathrm{~mm}$ Fura- 2 is sufficient to override the endogenous $\mathrm{Ca}^{2+}$-buffering mechanisms. For this purpose, $\mathrm{Ca}^{2+}$ entry was induced by activating voltage-gated $\mathrm{Ca}^{2+}$ currents in rat Purkinje neurons (P4-P7). During the time course of loading with $1 \mathrm{mM}$ Fura-2, depolarization-induced $\left[\mathrm{Ca}^{2+}\right]_{i}$ transients produced by comparable $\mathrm{Ca}^{2+}$ injections were mostly reduced (Fig. $4 A, B$ ). This observation alone indicates that Fura-2 was able to become the main intracellular $\mathrm{Ca}^{2-}$ buffer and to influence $\left[\mathrm{Ca}^{2+}\right]_{i}$ transients strongly in Purkinje neurons at this developmental stage. Moreover, when the $\mathrm{Ca}^{2+}$-sensitive fluorescence decrements were divided by the amount of incoming $\mathrm{Ca}^{2+}$ charge (giving the $F / Q$ ratio, see Materials and Methods) and plotted as a function of the intracellular Fura- $2 \mathrm{Ca}^{2+}$-buffering capacity (Neher and Augustine, 1992), a saturation of $F / Q$ ratios was apparent with increasing Fura-2-buffering capacities (data not shown). This finding strongly suggests that Fura-2, at a concentration of $1 \mathrm{~mm}$, becomes the dominant intracellular $\mathrm{Ca}^{2+}$ buffer in young Purkinje neurons.

In addition, a contribution of a $\mathrm{Ca}^{2+}$-induced $\mathrm{Ca}^{2+}$ release, caused by an escape from the $\mathrm{Ca}^{2+}$-buffering action of Fura-2, was excluded by two additional observations. First, in two experiments we used a higher concentration of Fura- 2 of $2 \mathrm{~mm}$ instead of $1 \mathrm{~mm}$. The fractional $\mathrm{Ca}^{2+}$ current measured under these conditions was not different from the other 6 cells. Second, for some cells we constructed a plot of $\mathrm{Ca}^{2+}$ charge versus total inward charge that entered the cell in the first $5 \mathrm{sec}$ of agonist application (Fig. $5 \mathrm{C}$ ). The relationship of these two parameters was linear, indicating that no regenerative mechanism of $\left[\mathrm{Ca}^{2+}\right]_{i}$ increase was recruited.

After complete loading of the cells with 1 or $2 \mathrm{~mm}$ Fura-2, and in the presence of $500 \mu \mathrm{M}$ D600 to block voltage-gated $\mathrm{Ca}^{2+}$ influx, ionic currents were evoked by iontophoretic application of AMPA or kainate, which caused a net total inward charge transport in the range of $1-15 \mathrm{nC}(10$ and $5 \mathrm{nC}$ in the examples of Fig. $4 C$ ). Despite the large total charge transport, the $\mathrm{Ca}^{2+}$ influx signals (see Fig. $4 C$, top) and, therefore, the contribution of $\mathrm{Ca}^{2+}$ to the total inward current through the AMPA-R channels were small. Because in many instances the $\mathrm{Ca}^{2+}$ influx signals were at the limit of the resolution of our measuring system, special care had to be taken for the quantification of the fractional $\mathrm{Ca}^{2+}$ current. In Figure 5, $A$ and $B$, two examples of analysis after iontophoretic application of kainate and AMPA to two different Purkinje neurons are shown. The decrement of the $\mathrm{Ca}^{2+}$-sensitive fluorescence of Fura-2 was fitted with the integral of the current response, scaled by the $F / Q$ ratio (Fig. $5 A, B$, dashed lines). A single-exponential $\mathrm{Ca}^{2+}$-extrusion mechanism was included in the simulation (Fig. $5 A, B$, solid lines). Using this approach, a single $F / Q$ ratio could be used to fit the data points from the beginning of the response to $>10-20 \mathrm{sec}$ later (see. Fig. $5 A, B$ ). During this time window, the $F / Q$-ratio parameter of the curve giving the best fit was divided by the $F_{\max }$ value to obtain an estimate of the fractional $\mathrm{Ca}^{2+}$ current (Schneggenburger et al., 1993a).

Using this analysis, an average fractional $\mathrm{Ca}^{2+}$ current of 0.57 $\pm 0.33 \%$ ( $n=4$ cells) was found with AMPA-induced currents at a holding potential of $-60 \mathrm{mV}$. When kainate was applied iontophoretically, the agonist-evoked currents usually decayed faster than with AMPA (see Fig. $5 A, B$ ). Consequently, the total amount of charge that entered the cell was too small to produce a $\mathrm{Ca}^{2+}$ signal that was readily measurable. To increase the total amount of charge transport, and therefore obtain a larger $\mathrm{Ca}^{2+}$ signal, a holding potential of $-80 \mathrm{mV}$ was used in the case of kainateinduced currents. The fractional $\mathrm{Ca}^{2+}$ current under these experimental conditions was $0.63 \pm 0.12 \%(n=4$ cells $)$. 

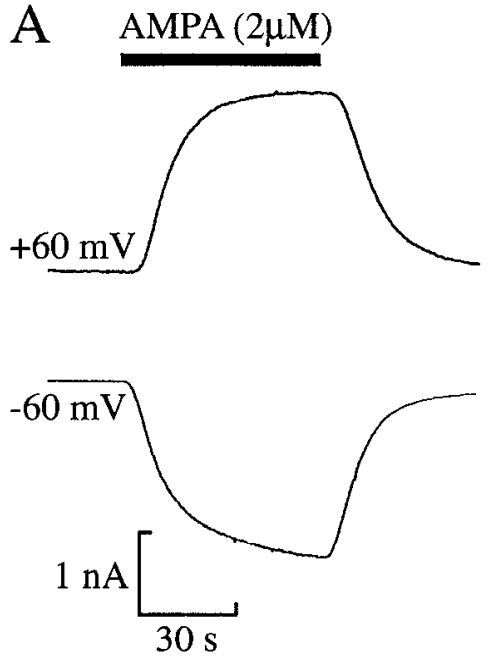

B kainate $(10 \mu \mathrm{M})$
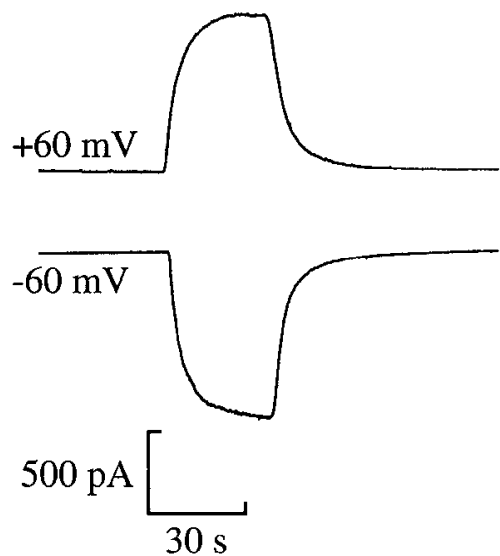

C kainate $(50 \mu \mathrm{M})$
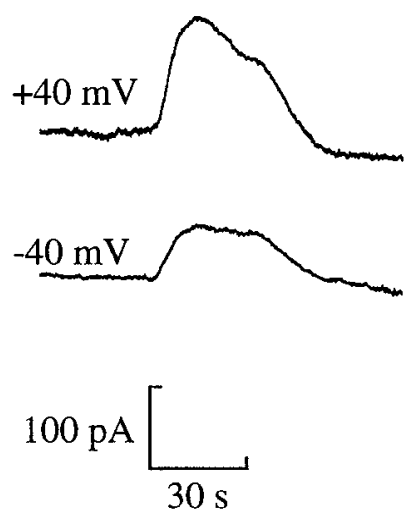
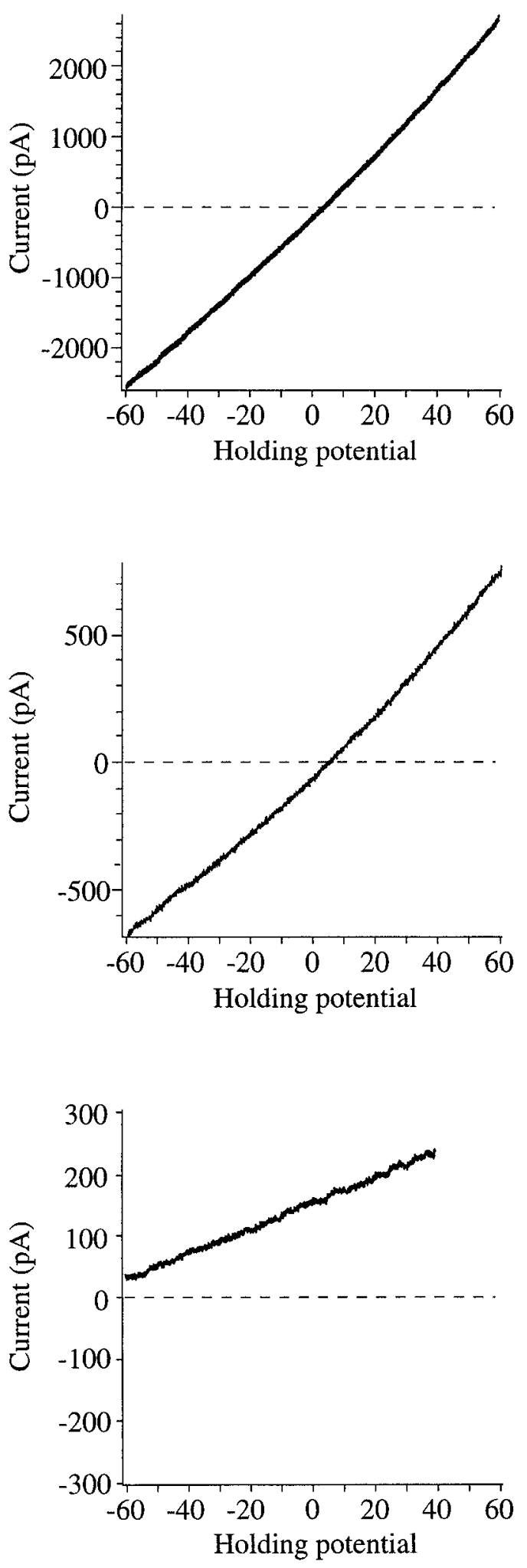

Figure 3. Conductance properties of AMPA-R channels of Purkinje neurons in cerehellar slices. A: Left, Currents recorded in a Purkinje neuron (P25) during bath applications of AMPA $(2 \mu \mathrm{M})$ at holding potentials of $+60 \mathrm{mV}$ (top) and $-60 \mathrm{mV}$ (bottom). Right, Currentvoltage relationship of the current evoked by bath-applied AMPA $(2 \mu \mathrm{M})$ measured during a voltage ramp from +60 to $-60 \mathrm{mV}$. B. Currents evoked in a Purkinje neuron (P8) by bath-applied kainate $(10 \mu \mathrm{M})$ at holding potentials of +60 and $-60 \mathrm{mV}$, and current-voltage relationship obtained with a voltage ramp applied during a kainate application. C, Currents evoked by bath applications of kainate $(50 \mu \mathrm{M})$ in a Purkinje neuron (P8) in a slice bathed in a $\mathrm{Na}^{+}$. free, high- $\mathrm{Ca}^{2+}(10 \mathrm{mM})$ extracellular solution. Extracellular $\mathrm{Na}^{+}$was replaced by $N$-methyl-D-glucamine. Left, Kainateinduced currents at holding potentials of +40 and $-40 \mathrm{mV}$. Right, Current-voltage relationship of the kainate-evoked current with a voltage ramp from +40 to $-60 \mathrm{mV}$.

\section{Single-cell RT-PCR analysis of GluR}

To correlate the data regarding the $\mathrm{Ca}^{2+}$-permeation properties of AMPA-R channels of Purkinje neurons with the expression pattern of the AMPA-R subunits, we used the recently introduced technique combining patch clamp with single-cell RT-PCR (Eberwine et al., 1992; Lambolez et al., 1992) applied to AMPA-R by
Lambolez et al. (1992). These experiments were performed in Purkinje neurons in slices of 5- to 7-d-old and 14- to 17-d-old rats. After the first PCR amplification, a single band containing fragments of $\sim 750 \mathrm{bp}$ (the expected fragments were $749 \mathrm{bp}$ for GluR1 and GluR2, 755 bp for GluR3, and 749 bp for GluR4) was detected by agarose-gel electrophoresis (Fig. $6 A$, lane 2). Contam- 


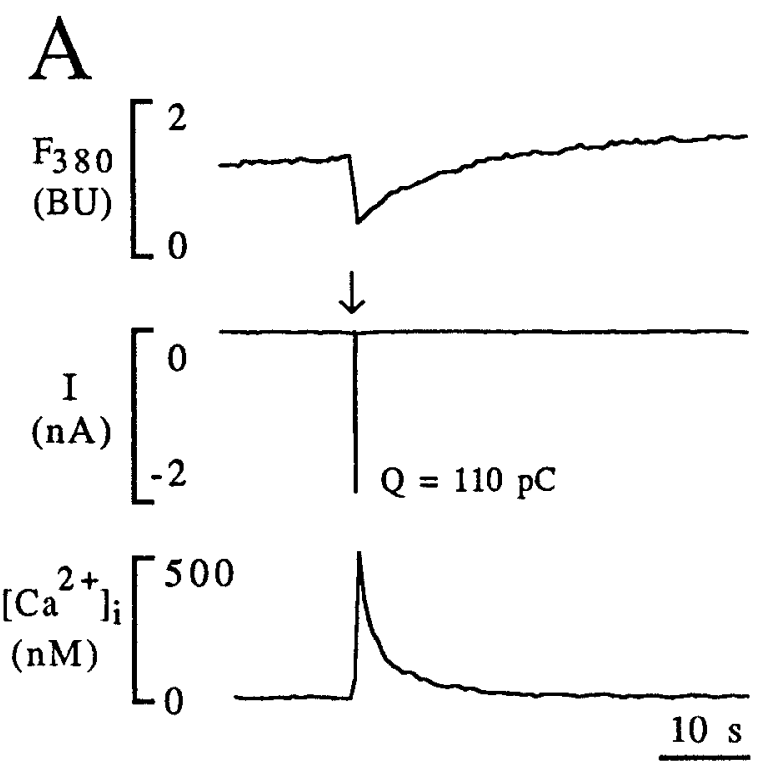

$\mathrm{B}$
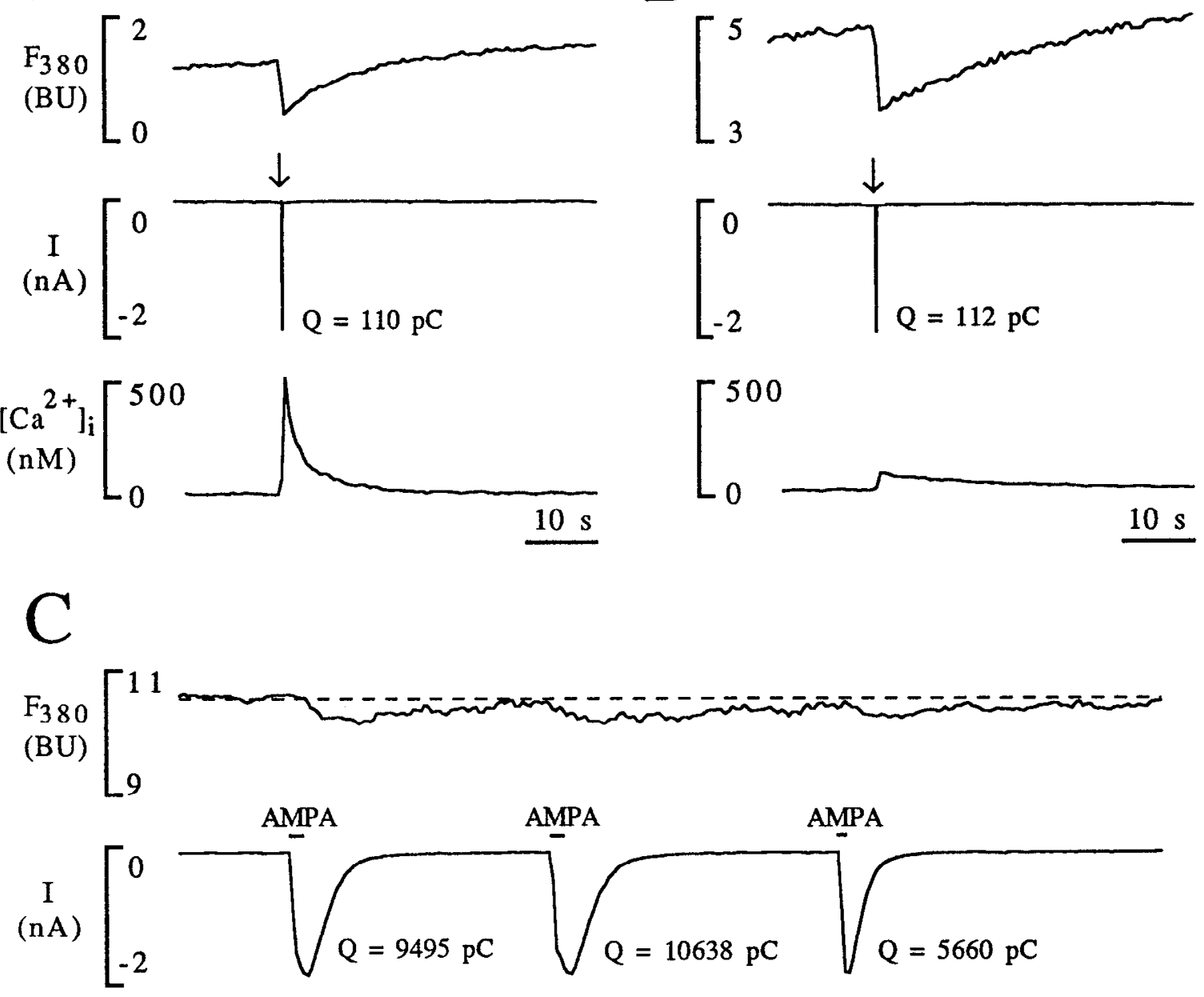

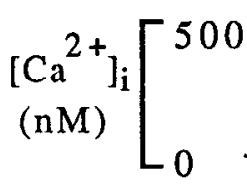

Figure 4. Fluorescence at the $\mathrm{Ca}^{2+}$-sensitive excitation wavelength $380 \mathrm{~nm}\left[F_{380}\right.$, expressed in bead units (BU)], patch clamp-recorded membrane current $(I)$, and $\left[\mathrm{Ca}^{2+}\right]_{\mathrm{i}}$ during direct membrane depolarizations $(A, B)$ or iontophoretic applications of AMPA $(C)$ in a Purkinje neuron in a cerebellar slice from a 5-d-old rat. $A$, Depolarizing step of $150 \mathrm{msec}$ duration from a holding potential of -60 to $+10 \mathrm{mV}$ (arrow) delivered at an early stage of loading with the fluorometric dye Fura-2 via the patch pipette. The inward current was carried almost exclusively by $\mathrm{Ca}^{2+}$ because $\mathrm{Na}^{+}$and $\mathrm{K}^{+}$channels were blocked (TTX, $0.5 \mu \mathrm{M}$; intracellular $\mathrm{Cs}^{+}, 130 \mathrm{mM}$; intracellular TEA ${ }^{+}, 20 \mathrm{mM}$ ). The charge $(Q)$ that entered in the cell, calculated as the time integral of the current, was 110 pC. $B$, Depolarizing step with the same parameters as in $A(Q=112 \mathrm{pC})$ but at a later stage of Fura-2 loading, as reflected by the different offset of the fluorescence at $380 \mathrm{~nm}$ (see calibration bar). Note the larger change in fluorescence associated with a considerably smaller $\mathrm{Ca}^{2+}$ transient. $C$, Three consecutive AMPA applications given after complete block of voltage-gated $\mathrm{Ca}^{2+}$ channels by D600 $(500 \mu \mathrm{M})$. Note that during the first two applications the total charge calculated from the inward currents $(Q)$ was $\sim 100$-fold larger than that with depolarizing steps but, nonetheless, the fluorescence changes were much smaller, indicating that $<1 \%$ of the AMPA-evoked current was carried by $\mathrm{Ca}^{2+}$.

ination by genomic DNA can be excluded because of the presence of three large introns between the two primer positions, which would have resulted in a larger amplification product. After purification and a second PCR amplification (see Materials and Methods for details), the product was investigated by restriction analysis with enzymes specific for each AMPA-R subunit (Fig. $6 A$ ). Fragments corresponding to the GluR1-GluR3 subunits were detected in all Purkinje neurons of both groups of younger $(\mathrm{P} 5-\mathrm{P} 7 ; n=8)$ and older $(\mathrm{P} 14-\mathrm{P} 17 ; n=6)$ rats. GluR4 was detected in two neurons from younger rats but was not detected in the older group. As a control, the same PCR reactions were performed on cDNA synthesized from total RNA prepared from whole brain of $17-d$-old rats. In this case, AMPA-R subunits GluR1-GluR4 were detected. To confirm the identity of the restriction fragments for GluR1-GluR4, Southern blot analysis was performed for 3 Purkinje neurons of P5 and P7 rats (Fig. $6 B$ ). Our data demonstrate that the AMPA-R of Purkinje neurons from 5 - to 7 -d-old and 14 - to 17 -d-old rats have a similar subunit 

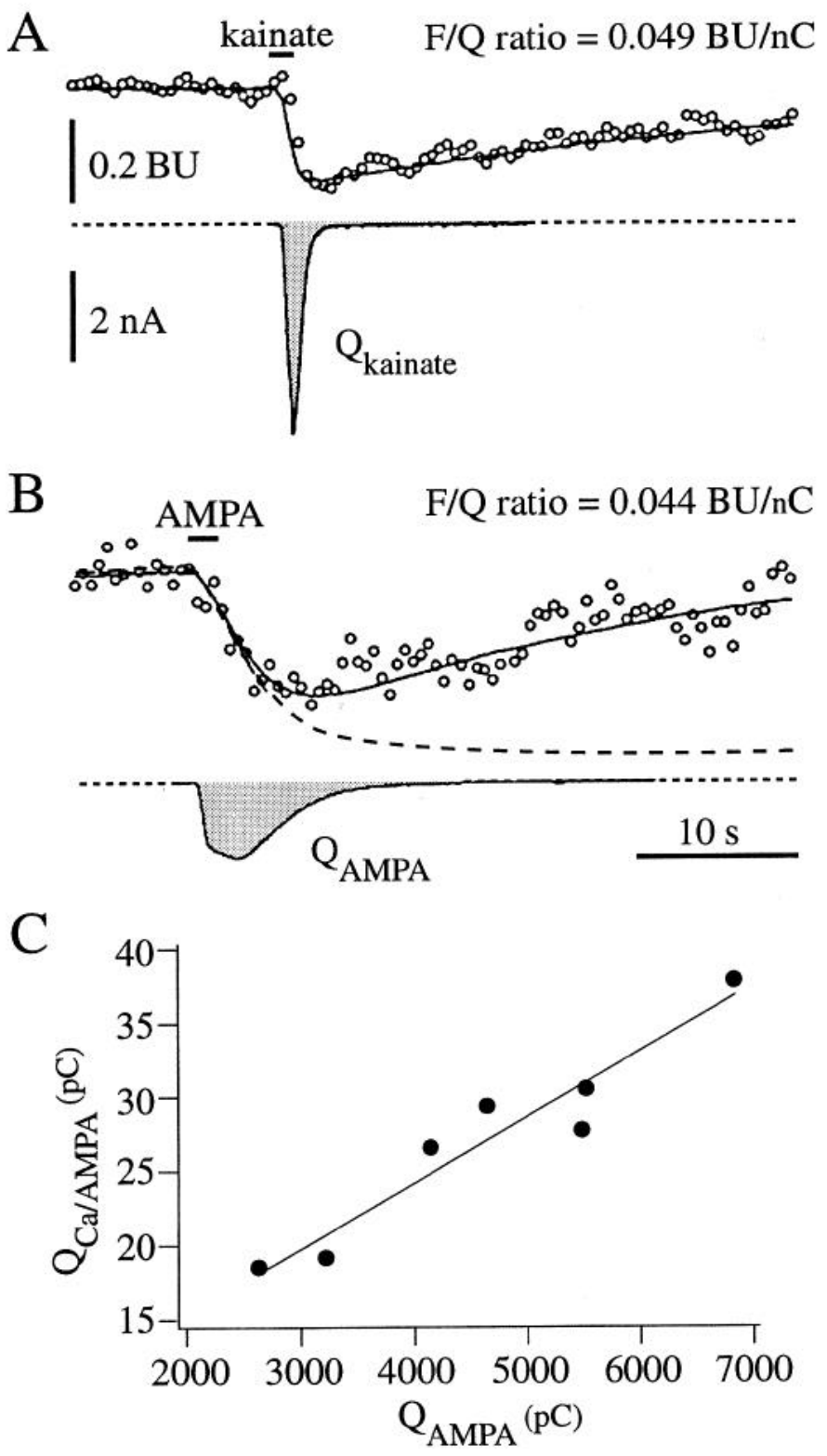

Figure 5. A, Fluorescence at $380 \mathrm{~nm}$ and simultaneously recorded membrane current during an iontophoretic application of kainate to a Purkinje neuron in a cerebellar slice from a 4-d-old rat. In the top trace, superimposed on the data points (open circles) are the time integral of the current scaled by the $F / Q$ ratio (dashed line) and the complete simulation, taking into account a single-exponential $\mathrm{Ca}^{2+}$-extrusion mechanism (solid line). The bottom trace represents the kainate-evoked inward current that was sampled throughout the experiment at the same rate as the fluorescence (dots) except at the time of iontophoretic applications, when it was sampled also at $500-1000 \mathrm{~Hz}$ (solid line). The shaded area in the current trace represents the total inward charge. $B$. Fluorescence at $380 \mathrm{~nm}$ and simultaneously recorded membrane current during an iontophoretic application of AMPA in a Purkinje neuron in a cerebellar slice from a 5-d-old rat. Note the early divergence of the integral (dashed line) from the simulation (solid line) caused by the slow time course of the AMPAevoked current. $C$, The $\mathrm{Ca}^{2+}$ charges entering the cell in the first $5 \mathrm{sec}$ of seven AMPA applications to a Purkinje neuron calculated from the simulation are plotted on the ordinate. The total inward charges in the same $5 \mathrm{sec}$ time window, calculated from the integral of the current trace recorded at high resolution ( $\operatorname{see} B$ ), are plotted on the abscissa. The data are fitted by a straight line, the slope of which represents the $\mathrm{Ca}^{2+}$ fraction of the current. Same cell as in $B$.
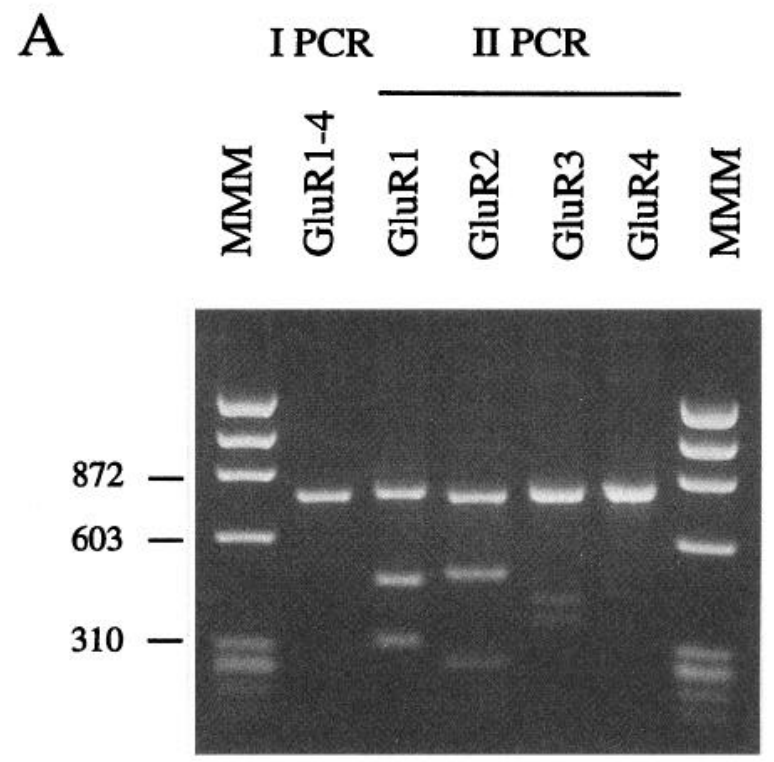

B

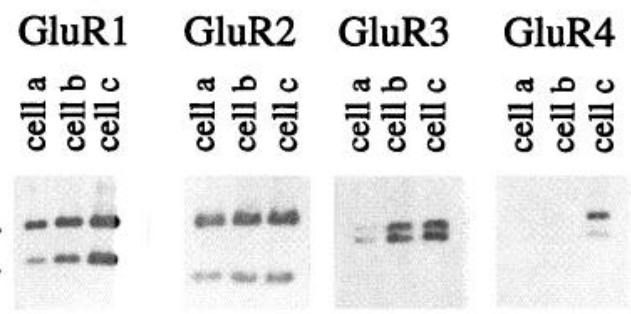

Figure 6. Expression of AMPA-R subunits in Purkinje neurons. A, Agarose-gel electrophoresis of the cDNA-amplified products from a single Purkinje cell at P5. Lanes 1 and 7 show the bands of the $\Phi X 174 / \mathrm{HaeIII}$ molecular-weight marker $(872,603$, and $310 \mathrm{bp}$ bands are indicated to the right of the gel). Lane 2 shows the $750 \mathrm{bp}$ band corresponding to the GluR1-GluR4 fragments after the first PCR. Lanes 3-6 show the cDNA fragments obtained after the second PCR reaction cut by $B g l \mathrm{I}$ ( 300 and $449 \mathrm{bp}$ ), Bsp $1286 \mathrm{I}$ (478 and $271 \mathrm{bp}$ ), Eco $47 \mathrm{III}$ (359 and $396 \mathrm{bp}$ ), and EcoRI (411 and 338 bp; specific for GluR1, GluR2, GluR3, and GluR4 cDNA fragments, respectively). $B$, Specificity of the amplified fragments demonstrated by Southern analysis using probes specific for GluR1-GluR4. The Southern blot is from an agarose gel (data not shown) of cDNA fragments, cut with restriction enzymes for GluR1-GluR4 (as in $A$ ), from three different Purkinje neurons (cells $a, b$, and $c$ ). Fragments of GluR1-GluR3 were marked in all three cells. GluR4 was detectable only in cell $c$. To see the restriction fragments for GluR4, twice as much DNA was applied to the agarose gel as for the other fragments, and longer exposure times were used.

composition and that the GluR2 subunit is expressed significantly at both of these stages of postnatal development.

\section{Patch-clamp recording combined with ratiometric digital imaging}

To test whether $\mathrm{Ca}^{2+}$ entering through AMPA-R channels was able to produce $\mathrm{Ca}^{2+}$ signals localized in the somatic or the dendritic region of Purkinje cells, $\left[\mathrm{Ca}^{2+}\right]_{i}$ was visualized by digital imaging during the application of AMPA-R agonists at a holding potential of $-60 \mathrm{mV}$. Figure $7 A$ shows $\left[\mathrm{Ca}^{2+}\right]_{\mathrm{i}}$ and the kainateinduced current from a Purkinje neuron of an 8-d-old rat. Application of kainate for $45 \mathrm{sec}$ induced an inward current with a peak amplitude of $\sim 2 \mathrm{nA}$ (Fig. $7 A$, top). The $\left[\mathrm{Ca}^{2+}\right]_{\mathrm{i}}$ calculated for the areas representing the soma and the dendrites (see inset) showed 

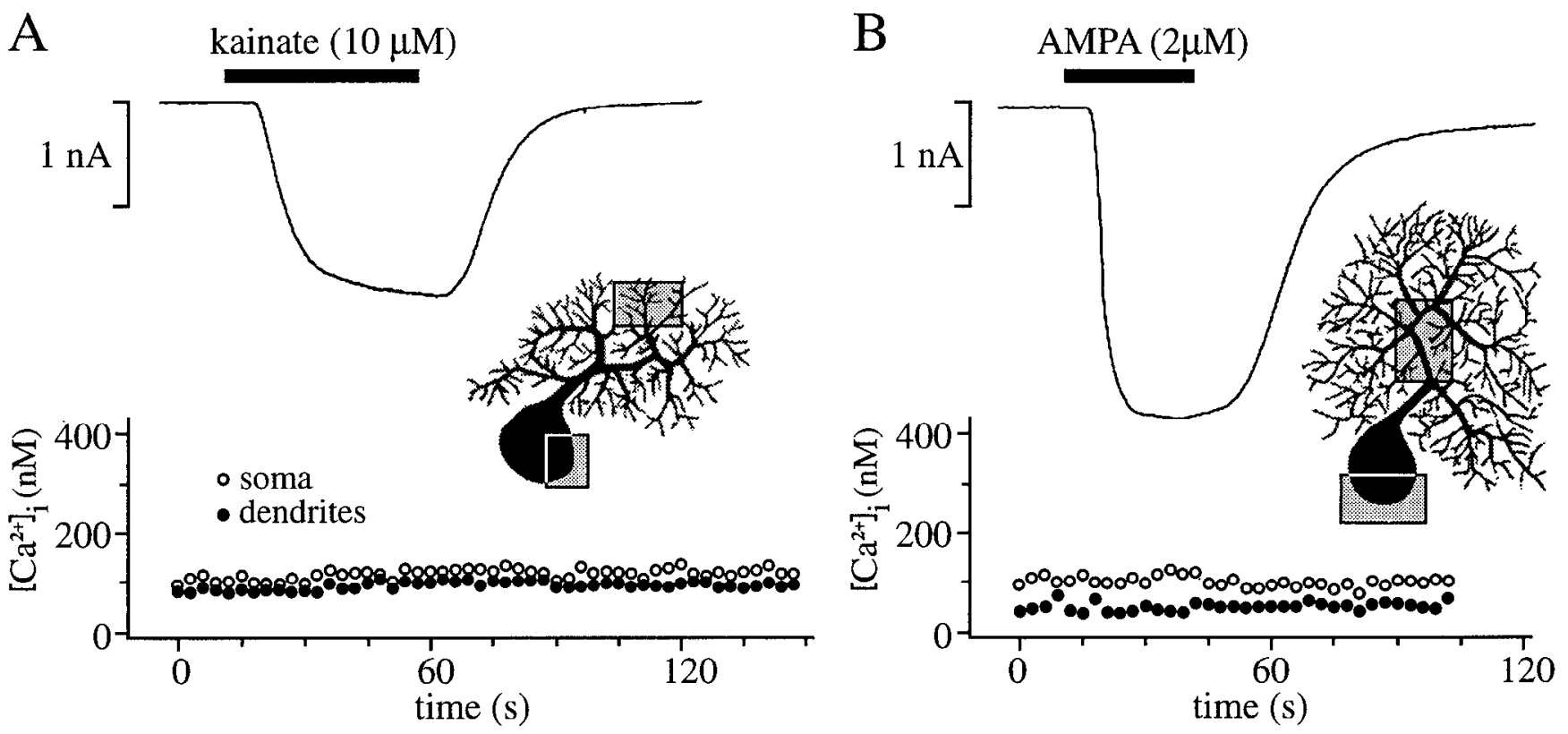

Figure 7. Simultaneous patch-clamp recording of membrane current (top) and DFI (insets and bottom traces) from somatic and dendritic regions of Purkinje neurons in rat cerebellar slices. Neurons were loaded with $0.2 \mathrm{~mm}$ Fura-2 via the patch pipette. $A$, Bath application of kainate (10 $\mu \mathrm{M})$ and associated monitoring of $\left[\mathrm{Ca}^{2+}\right]_{\mathrm{i}}$ in a Purkinje neuron from an 8-d-old rat. $B$, Bath application of AMPA $(2 \mu \mathrm{M})$ and associated monitoring of $\left[\mathrm{Ca}^{2+}\right]_{\mathrm{i}}$ in a Purkinje neuron from a 12 -d-old rat.

no increase during the kainate-induced inward current (Fig. $7 \mathrm{~A}$, bottom). Figure $7 B$ shows the AMPA-induced current and $\left[\mathrm{Ca}^{2+}\right]_{i}$ in the soma and dendrites of a Purkinje neuron of a 12-d-old rat (see inset). Despite the large current of $-3 \mathrm{nA}$, there was no detectable increase in $\left[\mathrm{Ca}^{2+}\right]_{\mathrm{i}}$ during the $30 \mathrm{sec}$ application of AMPA.

\section{DISCUSSION}

This report identifies AMPA-R channels of cerebellar Purkinje neurons as a type with a low $\mathrm{Ca}^{2+}$ permeability and, for the first time, provides a direct measurement of the fractional $\mathrm{Ca}^{2+}$ current through these AMPA-R channels in neurons.

\section{Screening of cells with a high $\mathrm{Ca}^{2+}$ permeability}

The technique of Fura-2 ester loading.combined with agonist application provides a useful tool for screening the $\mathrm{Ca}^{2+}$ permeability of AMPA-R channels that can be applied to Purkinje neurons at a wide range of developmental stages. Purkinje neurons showed no detectable increase in $\left[\mathrm{Ca}^{2+}\right]_{i}$ in response to AMPA-R-agonist applications, whereas under the same experimental conditions, clear elevations in $\left[\mathrm{Ca}^{2+}\right]_{i}$ were evoked in Bergmann glial cells. It is known from both molecular biological (Monyer et al., 1991; Burnashev et al., 1992a) and electrophysiological studies (Burnashev et al., 1992a; Müller et al., 1992) that Bergmann glia express AMPA-R channels with a high $\mathrm{Ca}^{2+}$ permeability. With this technique, we also observed a clear depolarization-induced increase in $\left[\mathrm{Ca}^{2+}\right]_{i}$ in Bergmann glia, a finding that suggests that voltage-gated $\mathrm{Ca}^{2+}$ channels are present in these glial cells, in contrast to previous electrophysiological reports (Müller et al., 1992).

\section{Voltage dependence of currents through AMPA-R channels}

The current-voltage relationship of AMPA-induced currents in normal extracellular solution was linear, with a slight outward rectification (see Fig. $3 A, B$ ). In experiments in which the only permeant extracellular cation was $\mathrm{Ca}^{2+}$, the current-voltage relationship was nearly linear, with a reversal potential more negative than $-60 \mathrm{mV}$ (Fig. 3C). The linearity of the current-voltage relationship allowed the reversal potential to be cstimated tentatively by extrapolation. For the cell shown in Figure $3 C$, this potential is approximately $-74 \mathrm{mV}$, a value (see lino et al., 1990; Jonas and Sakmann, 1992) that gives a permeability $(P)$ ratio $P_{\mathrm{Ca}} / P_{\mathrm{Cs}}$ of 0.19 . This value is close to the $P_{\mathrm{Ca}} / P_{\mathrm{Na}}$ of 0.17 found by Linden et al. (1993) for AMPA-R channels of cultured Purkinje neurons. Similar values $(0.10-0.18)$ were reported for the permeability ratios of $\mathrm{Ca}^{2+}$ to different monovalent cations for linearly conducting and outwardly rectifying AMPA-R channels in neurons of the spinal cord and hippocampus (Mayer and Westbrook, 1987; Iino et al., 1990; Lerma et al., 1994). However, for pyramidal neurons in slice preparations of the hippocampus and neocortex, lower values for $P_{\mathrm{Ca}} / P_{\mathrm{Cs}}$ of $<0.05$ (Jonas and Sakmann, 1992) and $P_{\mathrm{Ca}} / P_{\mathrm{K}}$ of $\sim 0.05$ (Jonas et al., 1994) were found, respectively. These and our values contrast markedly with those for AMPA-R with a higher $\mathrm{Ca}^{2+}$ permeability. In some hippocampal neurons, $P_{\mathrm{Ca}} / P_{\mathrm{Cs}}$ values of 2.3 (Iino et al., 1990 ) or 0.9 (Lerma et al., 1994) were obtained, whereas in neurons of the nucleus magnocellularis the value was 1.2 (Otis et al., 1995). In neocortical interneurons, a value for $P_{\mathrm{Ca}} / P_{\mathrm{K}}$ of 0.63 was found (Jonas et al., 1994).

\section{AMPA-R channels of Purkinje neurons have a low fractional $\mathrm{Ca}^{2+}$ current}

The fractional $\mathrm{Ca}^{2+}$ current value of $\sim 0.6 \%$ found in this report is in agreement with those calculated in different cell types from ion-substitution experiments. Using the Goldman-Hodgkin-Katz equation to convert the fractional $\mathrm{Ca}^{2+}$ current into a permeability ratio (see also Garaschuk et al., in press), we obtain a $P_{\mathrm{Ca}}$ $P_{\text {MonovalentCations }}$ of 0.13 , a value close to that of $\sim 0.19$ estimated from the current-voltage relationship in ion-substitution experiments (see above). This means that the permeability for $\mathrm{Ca}^{2+}$ is approximately sevenfold lower than for monovalent cations. These results 
are similar to those obtained by functional expression of AMPA-R in a heterologous system by Burnashev et al. (1995). The coexpression of the subunits GluR1 and GluR2(R) gives a fractional $\mathrm{Ca}^{2+}$ current of $0.54 \%$ in $1.8 \mathrm{mM} \mathrm{Ca}^{2+}$ and a $P_{\mathrm{Ca}} / P_{\mathrm{Cs}}$ of 0.05 from the reversal potential in $102 \mathrm{~mm}$ extracellular $\mathrm{Ca}^{2+}$. The $P_{\mathrm{Ca}} / P_{\mathrm{Cs}}$ calculated from $P_{\mathrm{f}}$ in $1.8 \mathrm{~mm}$ extracellular $\mathrm{Ca}^{2+}$ was 0.14 . Expression of GluR1 alone gave a $P_{\mathrm{f}}$ of $3.2 \%$.

In neurons of the medial septum, the fractional $\mathrm{Ca}^{2+}$ current was at least twice that measured in the present report for Purkinje neurons [1.2\% with AMPA (Schneggenburger et al., 1993b); 1.4\% with kainate (Schneggenburger et al., 1993a)], but was less than that for recombinant GluR1 expressed alone (Burnashev et al., 1995).

\section{Identification of the subunit composition of AMPA-R in Purkinje neurons}

With the RT-PCR of mRNA from single Purkinje neurons, mRNAs encoding for the subunits GluR1-GluR3 were readily detectable in all cells of both groups of 5- to 7-d-old and 14- to 17-d-old rats. The constant presence in all Purkinje neurons of the GluR2 subunit, which is known to produce AMPA-R channels with a low $\mathrm{Ca}^{2+}$ permeability when coexpressed with other AMPA-R subunits, is in contrast to the findings of a quantitativeassessment study of the mRNA of AMPA-R subunits in whole cerebellum using the in situ hybridization technique (PellegriniGiampietro et al., 1992). These authors propose that during early postnatal development AMPA-R channels of Purkinje neurons are highly $\mathrm{Ca}^{2+}$-permeable. However, there is conflicting evidence from the same research group. A second study using a Northern blot analysis of cerebellar RNA (Durand and Zukin, 1993) gave the opposite result and showed no significant change in the expression of GluR2 compared with GluR1 or GluR3. Our data suggest that if a switch from AMPA-R channels with a high $\mathrm{Ca}^{2+}$ permeability to those with a low permeability occurs for rat Purkinje neurons, the transition must take place prenatally.

In our study, we did not distinguish between the edited and unedited forms (Sommer et al., 1991) of the GluR2 subunit. However, a relevant expression of the unedited form is unlikely because data obtained by PCR analysis of rat brain RNAs (Burnashev et al., 1992b) show that the unedited form of the GluR2 subunit does not exceed $1 \%$ in prenatal [embryonic day 14 (E14) to P0] and $0.01 \%$ in early postnatal (P8) developmental stages. In addition, the current-voltage properties with $\mathrm{Ca}^{2+}$ as the only permeant extracellular cation and the low fractional $\mathrm{Ca}^{2+}$ current established in our study are in agreement with a strong expression of the edited form of the GluR2 subunit (Burnashev et al., 1992b).

The possibility remains that Purkinje neurons express different AMPA-R at different cellular sites. Furthermore, extrasynaptic receptors could be different from those at synaptic sites. Immunocytochemical studies have identified the presence of AMPA-R on the perikarya and dendrites of Purkinje neurons (Martin et al., 1993) and have shown that GluR1 is localized at both parallel- and climbing-fiber postsynaptic sites in adult rats (Baude et al., 1994). At the age used for the fractional $\mathrm{Ca}^{2+}$-current study (P4-P7), only climbing fibers form synapses acting on GluR of Purkinje neurons, whereas parallel fiber synapses develop later (Altman, 1972). In experiments in which the fractional $\mathrm{Ca}^{2+}$ current was measured, agonists were applied iontophoretically only to the soma. However, AMPA-R-mediated responses consistently displayed the same properties when assessed with different approaches such as bath applications of AMPA or kainate (present study), iontophoretic applications on the soma (present study), and parallel- and climbing-fiber stimulation (Llano et al., 1991b). In addition, with DFI, $\mathrm{Ca}^{2+}$ accumulation was detected neither in the soma nor in the dendrites. Thus, there is no evidence for significant variations in the expression of GluR2 in different regions of Purkinje neurons.

The similarity of the $P_{\mathrm{f}}$ values obtained in our study with AMPA and kainate as agonists suggests that, under our experimental conditions and at the postnatal age from which the data were obtained, high-affinity kainate-receptor channels, known to be expressed by Purkinje neurons (GluR5 and KA-1; see Wisden and Seeburg, 1993), likely do not play a significant role in our recordings. These suggestions are supported by the result of long iontophoretic applications of kainate during which no desensitizing component of current was observed (our unpublished observations). GluR5 is known to show desensitization (Sommer et al., 1992). Furthermore, cyclothiazide, a selective modulator of AMPA-R (Partin et al., 1993), removed desensitization of AMPA-induced currents and increased them fourfold (our unpublished observations).

Our results, which show that AMPA-R in Purkinje neurons in slices have a low $\mathrm{Ca}^{2+}$ permeability, are in agreement with those of Linden et al. (1993) but contrast with those of other groups using Purkinje neurons in culture (Brorson et al., 1992; Sorimachi, 1993). The reasons for these differences are unclear. One possibility is that other AMPA-R subunits are expressed under certain culture conditions.

In conclusion, our results show that AMPA-R in Purkinje neurons at all postnatal stages have a low $\mathrm{Ca}^{2+}$ permeability, consistent with the abundant expression of GluR2. Although the estimated $\mathrm{Ca}^{2+}$ permeability is low, it is not insignificant, $P_{\mathrm{f}}$ $(0.6 \%)$ being $\sim 0.06-0.09$ of that of the highly $\mathrm{Ca}^{2+}$-permeable NMDA-R (7-11\%) (Schneggenburger et al., 1993; Burnashev et al., 1995). No $\left[\mathrm{Ca}^{2+}\right]$, changes consistent with $\mathrm{Ca}^{2+}$ entry through AMPA-R were observed in the soma or dendrites of Purkinje neurons. This suggests that $\mathrm{Ca}^{2+}$ entry through AMPA-R does not contribute to the changes in $\left[\mathrm{Ca}^{2+}\right]_{i}$ involved in intracellular signaling in the control of synaptic plasticity. However, even this small amount of $\mathrm{Ca}^{2+}$ could be signiticant in a limited cellular compartment, e.g., dendritic spines, which have been observed to behave as functionally independent units (Guthric ct al., 1991; Müller and Connor, 1991; Koch and Zador, 1993).

\section{REFERENCES}

Altmann J (1972) Postnatal development of the cerebellar cortex in the rat. II. Phases in the maturation of Purkinje cells and of the molecular layer. J Comp Neurol 145:399-464.

Baude A, Molnar E, Latawiec D, McIlhinney RA, Somogyi P (1994) Synaptic and nonsynaptic localization of the GluR1 subunit of the AMPA-type excitatory amino acid receptor in the rat cerebellum. $J$ Neurosci 14:2830-2843.

Brorson JR, Bleakman D, Chard PS, Miller RJ (1992) Calcium directly permeates kainate/ $\alpha$-amino-3-hydroxy-5-methyl-4-isoxazolepropionic acid receptors in cultured cerebellar Purkinje neurons. Mol Pharmacol 41:603-608.

Burnashev N, Khodorova A, Jonas P, Helm PJ, Wisden W, Monyer H, Seeburg PH, Sakmann B (1992a) Calcium-permeable AMPA-kainale receptors in fusiform cerebellar glial cells. Science 256:1566-1569.

Burnashev N, Monyer H, Seeburg PH, Sakmann B (1992b) Divalent ion permeability of AMPA receptor channels is dominated by the edited form of a single subunit. Neuron 8:189-198.

Burnashev N, Zhou Z, Neher E, Sakmann B (1995) Fractional calcium currents through recombinant GluR channels of the NMDA, AMPA and kainate receptor subtypes. J Physiol (Lond) 485:403-418.

Chomczynski P, Sacchi N (1987) Single-step method of RNA isolation by acid guanidinium thiocynate-phenol-chlorophorm extraction. Anal Biochem 162:156-159. 
Durand GM, Zukin RS (1993) Developmental regulation of mRNAs encoding rat brain kainate/AMPA receptors: a Northern analysis study. J Neurochem 61:2239-2246.

Eberwine J, Yeh H, Miyashiro K, Cao Y, Nair S, Finncll R, Zettel M, Coleman P (1992) Analysis of gene expression in single live neurons. Proc Natl Acad Sci USA 89:3010-3014.

Edwards FA, Konnerth A, Sakmann B, Takahashi T (1989) A thin slice preparation for patch-clamp recordings from neurones of the mammalian central nervous system. Pflügers Arch 414:600-612.

Farrant M, Cull-Candy SG (1991) Excitatory amino acid receptorchannels in Purkinje cells in thin cerebellar slices. Proc R Soc Lond [Biol] 244:179-184.

Garaschuk O, Schneggenburger R, Schirra C, Tempia F, Konnerth A (1996) Fractional calcium currents through somatic and dendritic glutamate receptor channels of hippocampal CA1 pyramidal neurones. J Physiol (Lond), in press.

Grynkiewicz G, Poenie M, Tsien R (1985) A new generation of Ca indicators with greatly improved fluorescence propertics. J Biol Chem 260:3440-3450.

Guthrie PB, Segal M, Kater SB (1991) Independent regulation of calcium revealed by imaging dendritic spines. Nature 354:76-80.

Hollmann M, Heinemann S (1994) Cloned glutamate receptors. Annu Rev Neurosci 17:31-108.

Hollmann M, Hartley M, Heinemann S (1991) $\mathrm{Ca}^{2+}$ permeability of KA-AMPA-gated glutamate receptor channels depends on subunit composition. Science 252:852-853.

Hume RI, Dingledine R, Heinemann SF (1991) Identification of a site in glutamate receptor subunits that controls calcium permeability. Science 2.53:1028-1031.

Iino M, Ozawa S, Tsuzuki K (1990) Permeation of calcium through excitatory amino acid receptor channels in cultured rat hippocampal neurones. J Physiol (Lond) 424:151-165.

Jonas P, Sakmann B (1992) Glutamate receptor channels in isolated patches from CA1 and CA3 pyramidal cells of rat hippocampal slices. $\mathbf{J}$ Physiol (Lond) 455:143-171.

Jonas P, Racca C, Sakmann B, Seeburg PH, Monyer H (1994) Differences in $\mathrm{Ca}^{2+}$ permeability of AMPA-type glutamate receptor channels in neocortical neurons caused by differential GluR-B subunit expression. Neuron 12:1281-1289.

Kano M, Konnerth A (1992) Cerebellar slices for patch clamp recording. In: Practical electrophysiological methods (Kettenmann H, Grantyn R, eds), pp 54-57. New York: Wiley.

Kano M, Rexhausen U, Dreessen J, Konnerth A (1992) Synaptic excitation produces a long-lasting rebound potentiation of inhibitory synaptic signals in cerebellar Purkinje cells. Nature 356:601-604.

Keinänen K, Wisden W, Sommer B, Werner P, Hcrb A, Vcrdoorn TA, Sakmann B, Seeburg PH (1990) A family of AMPA-selective glutamate receptors. Science 249:556-560.

Koch C, Zador A (1993) The function of dendritic spines: devices subserving biochemical rather than electrical compartmentalization. J Neurosci 13:413-422.

Konnerth A, Dreessen J, Augustine GJ (1992) Brief dendritic calcium signals initiate long-lasting synaptic depression in cerebellar Purkinje cells. Proc Natl Acad Sci USA 89:7051-7055.

Lambolez B, Audinat E, Bochet P, Crépel F, Rossier J (1992) AMPA receptor subunits expressed by single Purkinje cells. Neuron 9:247--258.

I erma J, Morales M, Ibarz JM, Somohano F (1994) Rectification properties and $\mathrm{Ca}^{2+}$ permeability of glutamate receptor channels in hippocampal cells. Eur J Neurosci 6:1080-1088.

Linden DJ, Smeyne M, Connor JA (1993) Induction of ccrcbellar longterm depression in culture requires postsynaptic action of sodium ions. Neuron 11:1093-1100

Llano I, DiPolo R, Marty A (1994) Calcium-induced calcium release in cerebellar Purkinje cells. Neuron 12:663-673.

Llano I, Leresche N, Marty A (1991a) Calcium entry increases the sensitivity of cerebellar Purkinje cells to applied GABA and decreases inhibitory synaptic currents. Neuron 6:565-574.
Llano I, Marty A, Armstrong CM, Konnerth A (1991b) Synaptic- and agonist-induced excitatory currents of Purkinje cells in rat cerebellar slices. J Physiol (Lond) 434:183-213.

Llinás R, Sugimori M (1980) Electrophysiological properties of in vitro Purkinje cell somata in mammalian cerebellar slices. J Physiol (Lond) 305:171-195.

Martin LJ, Blackstone CD, Levey AI, Huganir RL, Price DL (1993) AMPA receptor subunits are differentially distributed in rat brain. Neuroscience 53:327-358.

Mayer ML, Westbrook GL (1987) Permeation and block of N-methyl-Daspartic acid receptor channels by divalent cations in mouse cultured central neurones. J Physiol (Lond) 394:501-527.

Momiyama A, Feldmeyer D, Cull-Candy SG (1995) Single channel characteristics of NMDA receptors in Purkinje cells in thin slices of neonatal rat cerebellum. J Physiol (Lond) 483:162P.

Monyer H, Seeburg PH, Wisden W (1991) Glutamate-operated channels: developmentally early and mature forms arise by alternative splic ing. Neuron 6:799-810.

Müller W, Connor JA (1991) Dendritic spines as individual neuronal compartments for synaptic $\mathrm{Ca}^{2+}$ responses. Nature 354:73-76.

Müller T, Möller T, Berger T, Schnitzer J, Kettenmann H (1992) Calcium entry through kainate receptors and resulting potassium-channel blockade in Bergmann glial cells. Science 256:1563-1566.

Neher E, Augustine GJ (1992) Calcium gradients and buffers in bovine chromaffin cells. J Physiol (Lond) 450:273-301.

Otis TS, Raman IM, Trussell LO (1995) AMPA receptors with high $\mathrm{Ca}^{2+}$ permeability mediate synaptic transmission in the avian auditory pathway. J Physiol (Lond) 482:309-315.

Partin KM, Patneau DK, Winters CA, Mayer ML, Bounanno A (1993) Selective modulation of desensitization at AMPA versus kainate receptors by cyclothiazide and concanavalin A. Neuron 11:1069-1082.

Pellegrini-Giampietro DE, Bennett MVL, Zukin RS (1992) Are $\mathrm{Ca}^{2+}$ permeable AMPA/kainate receptors more abundant in immature brain? Neurosci Lett 144:65-69.

Perkel DJ, Hestrin S, Sah P, Nicoll RA (1990) Excitatory synaptic currents in Purkinje cells. Proc R Soc Lond [Biol] 241:116-121.

Rogers M, Dani JA (1995) Comparison of quantitative calcium flux through NMDA, ATP, and ACh receptor channels. Biophys J 68:501-506

Sakurai M (1990) Calcium is an intracellular mediator of the climbing fiber in induction of cerebellar long-term depression. Proc Natl Acad Sci USA 87:3383-3385.

Schneggenburger R, Zhou Z, Konnerth A, Neher E (1993a) Fractional contribution of calcium to the cation current through glutamate receptor channels. Neuron 11:133-143.

Schneggenburger R, Tempia F, Konnerth A (1993b) Glutamate- and AMPA-mediated calcium influx through glutamate receptor channels in medial septal neurons. J Neuropharmacol 32:1221-1228.

Seeburg PH (1993) The molecular biology of mammalian glutamate receptor channels. Trends Ncurosci 16:359-365.

Sommer B, Burnashev N, Verdoorn TA, Keinänen K, Sakmann B, Seeburg PH (1992) A glutamate receptor channel with high affinity for domoate and kainate. EMBO J 11:1651-1656.

Sommer B, Keinänen K, Verdoorn TA, Wisden W, Burnashev N, Herb A, Köhler M, Takagi T, Sakmann B, Seeburg PH (1990) Flip and flop: a cell-specific functional switch in glutamate-operated channels of the CNS. Science 249:1580-1585.

Sommer B, Köhler M, Sprengel R, Seeburg PH (1991) RNA editing in brain controls a determinant of ion flow in glutamate-gated channels. Cell 67:11-20.

Sorimachi M (1993) Calcium permeability of non- $N$-methyl-D-aspartate receptor channels in immature Purkinje cells: studies using Fura-2 microfluorometry. J Neurochem 60:1236-1243.

Wisden W, Seeburg PH (1993) Mammalian ionotropic glutamate receptors. Curr Opin Neurobiol 3:291-298.

Zhou Z, Neher E (1993) Mobile and immobile calcium buffers in bovine adrenal chromaffin cells. J Physiol (Lond) 469:245-273. 